\title{
Etnomatematik dalam Bercocok Tanam Padi dan Kerajinan Anyaman Masyarakat Kampung Naga
}

\author{
Vepi Apiati1 ${ }^{*}$, Yeni Heryani², dan Siska Ryane Muslim³ \\ 1,2,3Fakultas Keguruan dan Ilmu Pendidikan, Universitas Siliwangi, Indonesia \\ Jalan Siliwangi No.24, Kahuripan, Tawang, Tasikmalaya, Jawa Barat 46115 \\ 1*vepiapiati@unsil.ac.id \\ ${ }^{2}$ yeniheryani@unsil.ac.id \\ ${ }^{3}$ siskaryanemuslim@unsil.ac.id
}

Artikel diterima: 03-12-2018, direvisi: 29-01-2019, diterbitkan: 31-01-2019

\begin{abstract}
Abstrak
Kampung naga merupakan kampung adat yang masih lestari, masyarakatnya memegang teguh tradisi nenek moyang mereka. Masyarakatnya menolak intervensi dari pihak luar jika hal itu mencampuri dan merusak kelestarian kampung tersebut. Disinilah peneliti mulai berpikir untuk mempelajari lebih dalam tentang kehidupan masyarakat Kampung Naga di Tasikmalaya. Mata pencaharian pokok masyarakat kampung naga adalah petani. Pendekatan penelitian yang digunakan dalam penelitian ini adalah pendekatan etnografi, yaitu pendekatan empiris dan teoretis yang bertujuan mendapatkan deskripsi dan analisis mendalam tentang kebudayaan berdasarkan penelitian lapangan yang intensif. Teknik pengumpulan data dilakukan dengan menetapkan informan, melakukan wawancara, membuat catatan etnografis, melakukan analisis. Teknik analisis data diantaranya reduksi data, penyajian data, dan verifikasi. Simpulan dalam penelitian ini Etnomatematik dalam bercocok tanam padi pada masyarakat kampung naga diantaranya penghitungan ganjil genap untuk menentukan benih padi yang akan ditanam. Biasanya di semester satu mereka menanam padi dengan jenis pare alit dan di semester kedua mereka menanam padi dengan jenis pare ageung. Etnomatematik dalam kerajinan anyaman masyarakat kampung naga adalah adanya penggunaan prinsif teselasi pada pola anyamannya.

Kata Kunci: Etnomatematik, pendekatan etnografi, Kampung Naga.
\end{abstract}

\section{Etnomatematik Implementation in Rice Farming and Craft Woven at Kampung Naga Society}

\begin{abstract}
Kampung Naga is a traditional village that is still sustainable, the community adheres to the traditions of their ancestors. The community refused intervention from outside parties if it interfered with and damaged the preservation of the village. This is where we began to think to learn more about the lives of the people of Kampung Naga in Tasikmalaya. The main livelihood of the Naga village community is farmers. The research approach used in this study is an ethnographic approach, namely an empirical and theoretical approach which aims to get a description and in-depth analysis of culture based on intensive field research. The technique of data collection is done by assigning informants, conducting interviews, making ethnographic notes, conducting analysis. Data analysis techniques include data reduction, data presentation, and verification. The conclusions in this research are ethnomatematics in matching rice farms in the Naga village community including an even-numbered odd calculation to determine the rice seeds to be planted. Usually in the first semester they plant rice with alit pare species and in the second semester they grow rice with pare ageung species. Ethnomatematics in woven crafts of the Naga village community is the use of principal tesellation on the woven pattern Keyword: Ethnomatematics, ethnographic approach, Kampung Naga.
\end{abstract}




\section{Pendahuluan}

Pertumbuhan dan perkembangan matematika terjadi karena adanya tantangan hidup yang dihadapi manusia di berbagai wilayah dengan berbagai latar belakang budaya yang berbeda. Setiap budaya mengembangkan matematika dengan cara mereka sendiri, sehingga matematika dipandang sebagai hasil akal budi (pikiran) manusia dalam aktivitas masyarakat sehari-hari melalui konteks pembelajaran (Afriansyah, 2016; Edo \& Samo, 2017). Hal ini sejalan dengan pendapat yang mengatakan bahwa matematika merupakan produk budaya yang merupakan hasil abstraksi pikiran manusia, serta alat pemecahan masalah. Integrasi nilai-nilai karakter (Maryati \& Priatna, 2017) dan budaya sangat penting untuk diterapkan dalam pembelajaran. Sebagaimana diungkapkan oleh Sembiring dalam Prabowo (2010) bahwa matematika adalah konstruksi budaya manusia.

Hasil dari sejarah budaya matematika dapat memiliki bentuk yang berbeda-beda dan berkembang sesuai dengan perkembangan masyarakat pemakainya. Etnomatematika menggunakan konsep matematika secara luas yang terkait dengan berbagai aktivitas matematika, meliputi aktivitas mengelompokkan, berhitung, mengukur, merancang bangunan atau alat, bermain, menentukan lokasi, dan lain sebagainya.

Budaya yang menjadi kebiasaan suatu kelompok atau masyarakat disebut kearipan lokal, kearifan lokal merupakan kecerdasan manusia yang dimiliki oleh kelompok etnis tertentu yang diperoleh melalui pengalaman masyarakat. Artinya pengalaman yang dimiliki oleh suatu masyarakat belum tentu dialami oleh masyarakat lain. Selanjutnya kearifan lokal memiliki ciri-ciri: mampu bertahan terhadap budaya luar, memiliki kemampuan mengakomodasi unsur-unsur budaya luar, mempunyai kemampuan mengintegrasikan unsur budaya luar ke dalam budaya asli, mempunyai kemampuan mengendalikan dan mampu memberi arah pada perkembangan budaya.

Sekelompok manusia dapat dikatakan sebagai masyarakat apabila memiliki pemikiran, perasaan, serta sistem/aturan yang sama. Paul B. Harton (dalam Rosa dan Orey, 2011) mengemukakan bahwa masyarakat adalah sekumpulan manusia yang secara relative mandiri, yang hidup bersama-sama cukup lama, yang mendiami suatu wilayah tertentu, memiliki kebudayaan yang sama, dan melakukan sebagian besar kegiatan dalam kelompok itu. Salah satu kelompok masyarakat yang menarik untuk dipelajari adalah masyarakat Kampung Naga Tasikmalaya.

Kampung naga merupakan kampung adat yang masih lestari, masyarakatnya memegang teguh tradisi nenek moyang mereka. Masyarakatnya menolak intervensi dari pihak luar jika hal itu mencampuri dan merusak kelestarian kampung tersebut. Disinilah kami mulai berpikir untuk mempelajari lebih dalam 
tentang kehidupan masyarakat Kampung Naga di Tasikmalaya.

Etnomatematika merupakan istilah baru dalam matematika yang mengaitkan budaya dengan konsep matematika. Istilah etnomatematika dikemukakan pertama kali oleh D'Ambrosia (1977) seorang matematikawan Brazil dengan pendefinisian sebagai berikut: "The prefix ethno is today accepted as a very broad term that refers to the socialcultural context and therefore includes language, jargon, and codes of behavior, myths, and symbols. The derivation of mathema is difficult, but tends to mean to explain, to know, to understand, and to do activities such as ciphering, measuring, classifying, inferring, and modeling. The suffix tics is derived from techné, and has the same root as technique" (Rosa \& Orey 2011). Etnomatematika dapat diartikan sebagai matematika yang dipraktikan oleh kelompok budaya, seperti masyarakat perkotaan dan pedesaan, kelompok buruh, anak-anak dari kelompok usia tertentu, masyarakat adat dan lainnya. D'Ambrosia (1985) menyatakan bahwa tujuan dari adanya etnomatematika adalah untuk mengakui bahwa ada cara-cara berbeda dalam memperlakukan matematika dengan mempertimbangkan pengetahuan matematika akademik yang dikembangkan oleh berbagai sektor masyarakat serta dengan mempertimbangkan modus yang berbeda dimana budaya yang berbeda merundingkan praktek matematika mereka (cara mengelompokkan, berhitung, mengukur, merancang bangunan atau alat, bermain dan sebagainya).

Menurut Barton (1994: 196), etnomatematika merupakan kajian yang meneliti cara sekelompok orang dari budaya tertentu mengekspresikan, konsep-konsep kebudayaannya yang digambarkan oleh peneliti sebagai sesuatu yang matematis. Oleh karena Ethnomathematics adalah sebuah kajian keilmuan haruslah memiliki objek kajian. Objek kajian dari etnomatematika yaitu untuk mengungkap organisasi dari ide (konsep) yang tidak terpisah dari aktivitas matematika. Objek kajian etnomatematika didapatkan dengan dua cara yaitu: (1) menginvestigasi aktivitas matematika yang terdapat dalam kelompok budaya tertentu; (2) mengungkap konsep matematis yang terdapat dalam aktivitas tersebut (Barton, 1994: 196). Atas dasar pentingnya pengaitan budaya dengan pembelajaran matematika, maka penelitian etnomatematika perlu mendapat ruang.

Kampung Naga berada di lembah yang terletak di desa Neglasari kecamatan Salawu Kabupaten Tasikmalaya Propinsi Jawa Barat. Tata letak rumah dan arsitesktur yang khas dan masih mempertahankan kearifan lokal dan budaya yang mereka jaga sejak bertahuntahun. Sebelah selatan kampung naga dibatasi oleh sawah-sawah penduduk dan sebelah utara dan timur dibatasi oleh Ciwulan yang sumber airnya berasal dari gunung Cikuray di daerag Garut. Jarak tempuh dari kota Tasikmalaya kurang lebih 
30 km, sedang kan kota Garut jaraknya 26 $\mathrm{km}$.

Rumah masyarakat Kampung Naga berbentuk panggung, bahan rumah dari bambu dan kayu, atap rumahnya dari daun nipah, ijuk atau alang-alang, lantai rumah terbuat dari bambu atau papan kayu, dinding rumah dari bilik atau anyaman bambu dengan anyaman sasag. Rumah tidak boleh dicat kecuali dikapur atau dimeni. Bahan rumah tidak boleh menggunakan tembok walaupun mampu membuat rumah tembok atau gedung. Rumah harus menghadap ke utara atau ke selatan dengan memanjang ke arah barat - timur.

Masyarakat kampung naga memiliki kepercayaan bahwa ruang atau tempat memiliki batas-batas tertentu yang masing-masing dikuasai oleh kekuatankekuatan tertentu. Diantaranya batas sungai, batas pekarangan rumah dengan jalan, batas antara sawah dengan selokan, batas batas perkampungan dengan hutan, dan batas tempat air mulai masuk yang sering disebut dengan huluweton. Kekuatan-kekuatan yang mendiami batasbatas tersebut berupa mahluk-mahluk halus dan dianggap angker atau sanget.

Teselasi merupakan suatu pola khusus yang terdiri dari bangun-bangun geometri yang disusun tanpa pemisah/jarak untuk menutupi suatu bidang datar. Istilah lain yang sering digunakan untuk menyebut teselasi adalah pengubinan. Rokhmah menyatakan "Teselasi atau pengubinan merupakan konsep antar cabang ilmu pengetahuan yaitu matematika dan seni" 110 (p.1). Ketika teselasi digunakan oleh beberapan seniman dan penganyam, teselasi mengacu pada konsep artistik. Sedangkan dalam pembelajaran matematika, teselasi meliputi beberapa konsep-konsep matematika yang lebih dalam seperti segi banyak beraturan, segi banyak tidak beraturan, kekongruenan, sudut dalam, jumlah sudut dalam suatu segi banyak, simetri, translasi, refleksi, dan rotasi.

Berdasarkan latar belakang yang telah dikemukakan sebelumnya, maka rumusan masalah dalam penelitian ini yaitu: bagaimanakah etnomatematika dalam bercocok tanam padi dan kerajinan anyaman yang ada pada masyarakat kampung naga.

\section{Metode}

Pendekatan penelitian yang digunakan dalam penelitian ini adalah pendekatan etnografi, yaitu pendekatan empiris dan teoretis yang bertujuan mendapatkan deskripsi dan analisis mendalam tentang kebudayaan berdasarkan penelitian lapangan yang intensif. Pendekatan ini memusatkan usaha untuk menemukan bagaimana masyarakat mengorganisasikan budaya mereka dalam pikiran mereka dan kemudian menggunakan budaya tersebut dalam kehidupan manusia.

Dalam penelitian ini, menggunakan metode penelitian deskriptif kualitatif. David Williams (dalam Moleong, 2011) mengemukakan bahwa penelitian kualitatif adalah pengumpulan data pada suatu latar ilmiah dengan menggunakan Mosharafa: Jumal Pendidikan Matematika Volume 8, Nomor 1, Januari 2019 Copyright $\odot 2019$ Mosharafa: Jurnal Pendidikan Matematika 
metode alamiah, dan dilakukan oleh orang atau peneliti ilmiah yang tertarik secara alamiah (p.5). Dalam penelitian ini peneliti berusaha menggali informasi melalui kepustakaan, pengamatan (observasi) serta proses wawancara dengan beberapa warga pengrajin anyaman di kampung naga. Jenis penelitian deskriptif kualitatif yang digunakan pada penelitian ini dimaksudkan untuk memperoleh informasi mengenai matematika dalam perspektif budaya. Selain itu dengan pendekatan kualitatif diharapkan dapat mengungkapkan situasi dan permasalahan yang dihadapi masyarakat kampung naga.

Teknik Pengunpulan data yang dilakukan diantaranya: menetapkan informan, melakukan wawancara terhadap informan, membuat catatan etnografis, mengjukan pertanyaan deskriptif, melakukan analisis wawancara etnografis, melakukan analisis domain, mengajukan pertanyan structural, mengajukan analisis taksonomi, dan menulis etnografi.

Analisis data kualitatif akan mengacu kepada penelusuran data dan catatancatatan untuk menemukan pola budaya yang akan dikaji. Analisis data yang akan dilakukan dalam penelitian ini mengacu pada model Miles and Huberman, yaitu: reduksi data, penyajian data, dan verifikasi. Penelitian ini dilakukan selama 4 bulan pada semester ganjil.

\section{Hasil dan Pembahasan}

Masyarakat kampung naga mengaku keturunan dari Eyang Singaparna, pewaris terakhir tahta kerajaan Galunggung yang

\section{Mosharafa: Jurnal Pendidikan Matematika}

Volume 8, Nomor 1, Januari 2019

Copyright @ 2019 Mosharafa: Jurnal Pendidikan Matematika beragama Islam. Berada pada suatu lembah yang subur dan cocok untuk lahan pertanian. Di kampung tersebut mengalir sungai Ciwulan yang digunakan untuk mencukupi kebutuhan air di kampung tersebut.

Lahan pesawahan juga dilengkapi dengan petak dan pematang sehingga sawah menjadi berteras mengikuti garis kontur (ngais gunung). Keadaan tersebut merupakan salah satu konservasi lahan. Adanya teras pada sawah yang mengikuti garis kontur dan petak yang hampir datar seperti pematang berfungsi untuk menahan air. Petak dan pematang akan menahan aliran air yang pelan-pelan dari satu petak ke petak lainnya, sehingga melindungi tanah dari erosi.

Masyarakat kampung naga sebagian besar bermata pencaharian sebagai petani sawah. Masyarakatnya menerapkan suatu pantangan atau pamali menanam padi hawara atau hibrida di lahan pesawahannya. Padi yang umumya ditanam dan merupakan padi lokal masyarakat kampung naga adalah pare ageung dan pare alit. Waktu atau usia padi tersebut dari mulai ditanam sampai panen kurang lebih selama 6 bulan, jadi periode tanam padinya dua kali dalam setahun.

Masyarakat kampung naga menentukan benih mana yang akan mereka tanam dengan menggunakan penghitungan ganjil genap. Biasanya di semester satu (bilangan ganjil) mereka menanam padi dengan jenis pare alit dan di semester kedua (bilangan genap) 
mereka menanam padi dengan jenis pare ageung.

Pada saat menanam padi dengan jenis pare alit atau sering disebut dengan segon, tidak berarti nanti hasil panennya sedikit. Pare alit memiliki sifat nyeuweu artinya makin banyak. Jadi benih yang ditanam di sawahnya akan semakin berkembang atau bertambah banyak. Dalam satu aray (40 bata) masyarakat kampung naga menanam padi hanya sebanyak satu geugeus (2 endan).

Proses penanaman padi dimulai dengan merendam benih dalam air selama dua hari, kemudian mengangkatnya kembali ke darat dan dibiarkannya sampai benih tersebut berkecambah. Benih padi yang sudah berkecambah kemudian disebarkan di suatu tempat yang disebut dengan istilah tebar. Satu bulan kemudian dilakukan babut yaitu mencabut benih yang sudah disebar untuk dipindahkan atau ditanam kembali di lahan pesawahan yang disebut dengan istilah tandur. Jarak antar bibit padi tersebut berbeda-beda tergantung jenis padi yang ditanam. Untuk padi jenis pare alit (segon) berjarak $30 \mathrm{~cm}$ dan untuk padi jenis pare ageung berjarak $40 \mathrm{~cm}$. Agar jarak antar bibit padi tersebut sama mereka menggunakan sebuah alat yang dinamakan caplakan.

Setelah 15 hari dilakukan pemupukan terhadap bibit padi yang sudah ditanam di pesawahan. Masyarakat kampung naga menggunakan pupuk organik yang mereka olah sendiri dengan campuran kotoran hewan dan campuran bahan-bahan lainnya yang masih alami. Dalam mengolah 112 pupuk organic tersebut sudah turun temurun ada dari jaman nenek moyangnya dulu. Sebagian besar penduduk kampung naga beranggapan bahwa pupuk anorganik dapat merusak lingkungannya.

Empat bulan kemudian, tanaman padi sudah mulai berbuah dan masyarakat di kampung naga menyebutnya pare beukah. Sebulan kemudian dibulan ke lima sudah semakin berisi (beuneur hejo) dan tidak lama kemudian berubah warna menjadi kuning (miang koneng) siap untuk dipanen. Dalam memanen hasil pertaniannya, masyarakat kampung naga masih menggunakan ani-ani tidak menggunakan mesin pemotong atau perontok padi. Setelah padi dipotong dengan ani-ani kemudian padi tersebut dijemur sampai kering dan ditumbuk dengan menggunakan lesung dan halu, penyusutan hasil panen lebih sedikit dan nasi lebih enak di makan dibandingkan dengan menggunakan mesin perontok padi.

Penumbukkan padi ini dilakukan di saung lisung yang sengaja dibuat di atas kolam (balong) supaya limbah dari penumbukkan padi (ngalisung) berupa dedak (hu'ut) dan potongan-potongan beras yang kecil (beuyeur) langsung jatuh ke kolam dan menjadi makanan ikan peliharaannya. Masyarakat kampung naga menganggap padi lokal membawa banyak berkat. Mereka tidak pernah kekurangan padi atau beras dalam setiap siklus atau putaran masa penanaman padi sampai panen. Hasil panen padi disimpan dalam lumbung padi (leuit) yang merupakan Mosharafa: Jurnal Pendidikan Matematika Volume 8, Nomor 1, Januari 2019 Copyright $\odot 2019$ Mosharafa: Jurnal Pendidikan Matematika 
sistem ketahanan pangan yang mampu menopang petani pada saat gagal panen atau paceklik.

Masyarakat kampung naga, di sela-sela kesibukannya sebagai petani mereka mengisi waktu luangnya untuk membuat kerajinan berupa anyaman yang berasal dari bambu. Berbagai jenis kerajinan mereka buat dengan cara yang mereka pelajari secara turun temurun.

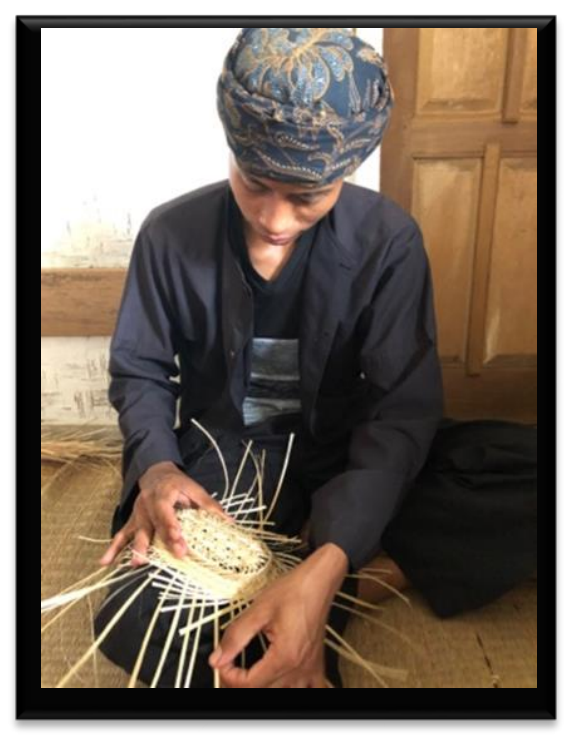

Gambar 1. Menganyam.

Bambu merupakan bahan bangunan yang hingga kini digunakan oleh masyarakat sunda khususnya masyarakat Kampung Naga. Sasag dan bilik merupakan anyaman dasar masyarakat kampung naga yang bahan bakunya adalah bambu. Sasag horizontal digunakan untuk dinding dapur dan sasag vertical digunakan untuk pintu dapur. Jenis anyaman sasag paling banyak digunakan karena kuat dan tahan lama. Penggunaan anyaman bercelah tersebut harus disesuaikan dengan ketentuan adat.
Selain digunakan untuk sasag dan bilik, anyaman juga digunakan warga kampung naga untuk membuat berbagai macam kerajinan tangan seperti tampah, kap lampu, piring, dan topi caping. Hasil anyaman bambu tidak hanya memiliki fungsi praktis tetapi juga memiliki fungsi estetis. Dengan kreativitas banyak terdapat berbagai karya dari anyaman bambu yang telah dibuat oleh masyarakat kampung naga. Pada proses pembuatan anyaman bambu meliputi tahap penebangan, pengawetan, pemotongan, pembelahan, penjemuran, dan penganyaman.

Teselasi merupakan satu pola khusus yang terdiri dari bangun-bangun geometri yang disusun tanpa pemisah atau jarak untuk menutupi suatu bidang datar. Teselasi juga merupakan konsep antar cabang ilmu pengetahuan yaitu matematika dan seni. Ketika teknik teselasi oleh seniman tukang batu, teselasi mengacu pada pada konsep artistic. Sedangkan dalam pembelajaran matematika teselasi meliputi beberapa konsep matematika yang lebih dalam seperti segi banyak beraturan, segibanyak tidak beraturan, kekongruenan, sudut dalam, jumlah suatu sudut dalam segi banyak, simeri, translasi, refleksi dan rotasi.

Konsep matematika yang ada pada anyaman masyarakan kampung naga adalah teselasi. Karena adanya penerapan konsep matematika dalam anyaman kerajinan masyarakat kampung naga. Konsep teselasi diharapkan dapat

\section{Mosharafa: Jurnal Pendidikan Matematika} 113 
menemukan bentuk-bentuk bangun diantaranya tengkor dan kipas. Tengkor geometri yang terdapat dalam kerajinan tersebut.

atau pincuk anyaman bambu merupakan peralatan rumah tangga yang digunakan

Kerajinan anyaman bambu yang dibuat oleh masyarakata kampung naga makanan seperti lotek dan pecel.

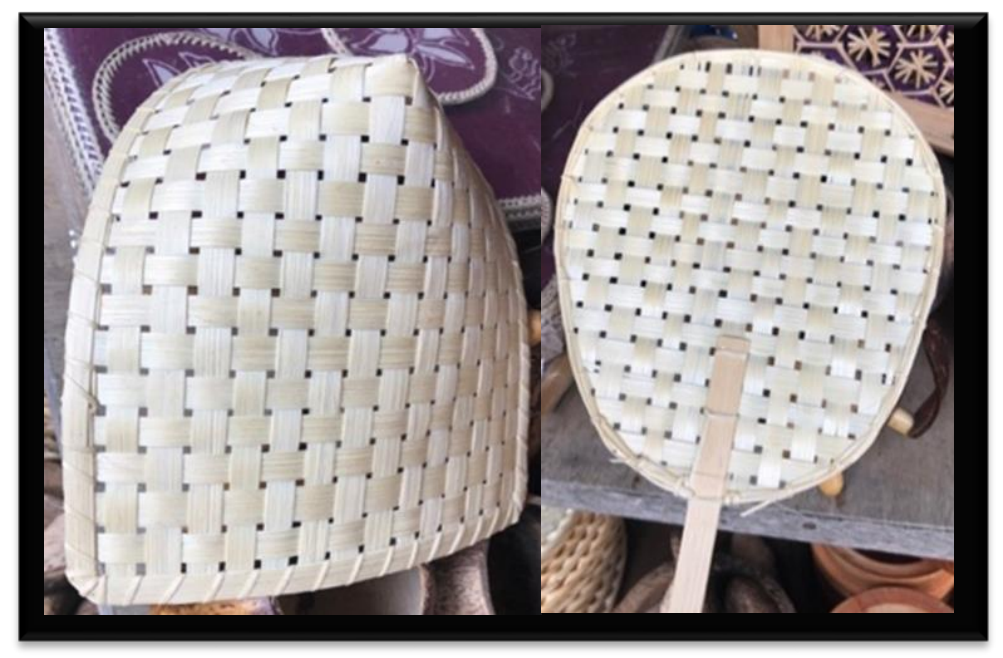

Gambar 2. Tengkor dan Kipas.

Bangun geometri yang terdapat dalam kerajinan masyarakat kampung naga tersebut digolongkan pada Regular Tesselation. Anyaman tengkor menyerupai bangun geometri kerucut dan anyaman kipas menyerupai bangun geometri ellips. Teknik dasar anyaman ini seperti teknik anyaman bilik. Hasil dari teknik dasar anyaman ini adalah anyaman tiga sumbu jarang dan anyaman tiga sumbu rapat. Sumbu jarang memberikan lubang yang renggang dan sumbu rapat akan memberikan kekuatan yang lebih kuat.

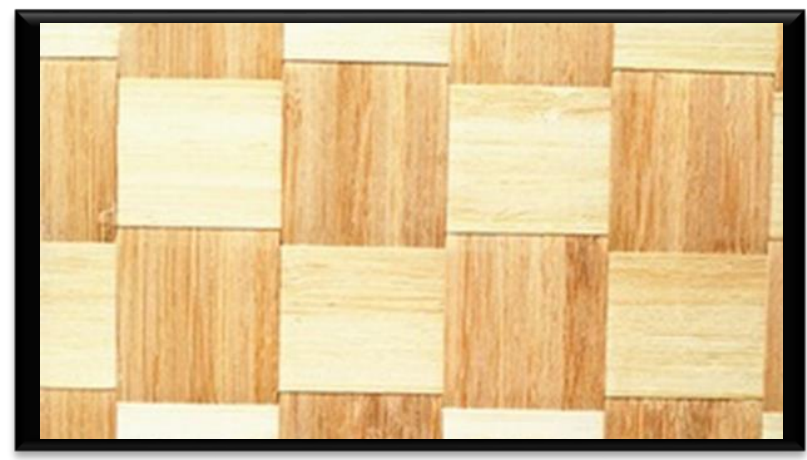

Gambar 3. Unsur Matematika pada Pola Anyaman. 
Beberapa unsur matematika yang ada dalam pola anyaman tersebut diantaranya: bangun geometri persegi, antara persegi yang satu dengan yang lainnya simetris, sudut-sudut yang dibentuk adalah sudut siku-siku, garis horizontal tegak lurus dengan garis vertikal, antara garis horizontal yang satu dan yang lain saling sejajar, begitu pula antara garis vertical yang satu dengan yang lainnya saling sejajar. Kerajinan anyaman lainnya diantaranya: piring alas buat makan.

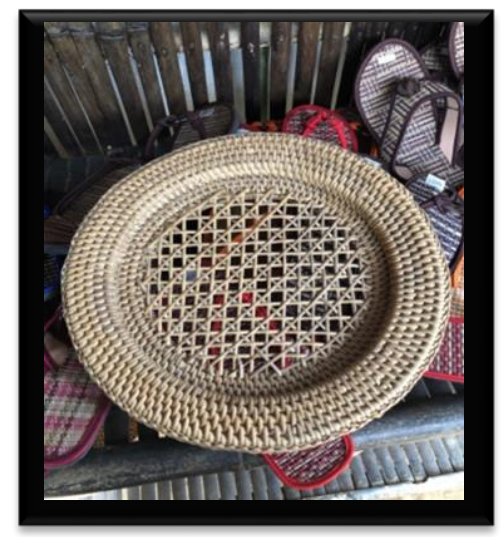

Gambar 4. Piring alas makan.

Bangun geometri yang terdapat dalam kerajinan masyarakat kampung naga tersebut digolongkan pada Semiregular Tesselation. Anyaman piring alas berbentuk bangun geometri lingkaran.
Anyaman ini termasuk ke dalam anyaman tiga sumbu. Khusus untuk anyaman tiga sumbu rapat, apabila dibentuk dengan pola bentuk heksagonal/segi enam beraturan disebut dengan anyaman segi enam.

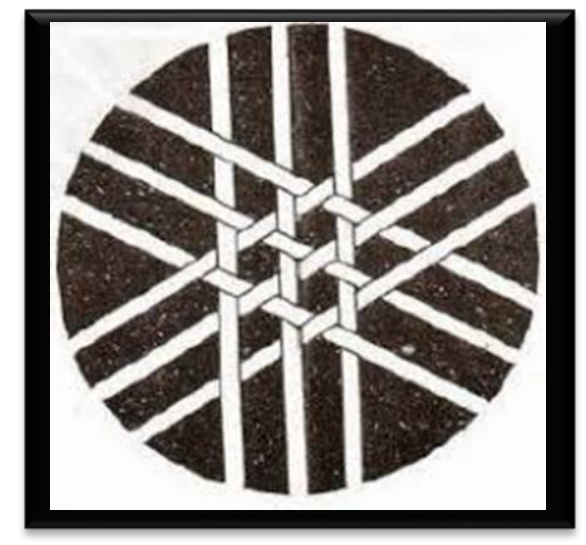

Gambar 5. Unsur Matematika pada Pola Anyaman.

Beberapa unsur matematika yang lain yang ada dalam pola anyaman tersebut diantaranya: bangun geometri segi enam/heksagonal, sudut yang saling berhadapan sama besar.

Kerajinan anyaman lainnya yang dibuat oleh masyarakat kampung naga diantaranya: piring snek, dan rigen piring, 


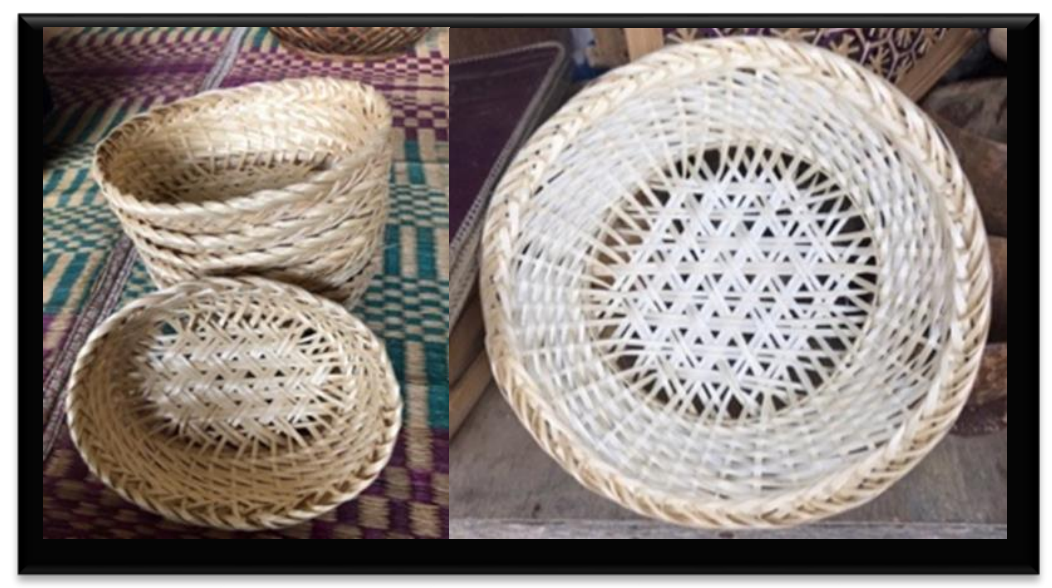

Gambar 6. Piring Snek.

Bangun geometri yang terdapat dalam kerajinan masyarakat kampung naga tersebut digolongkan pada A Demi Reguler Tesselation. Anyaman piring snek berbentuk bangun geometri ellips dan rigen piring membentuk bangun geometri lingkaran. Anyaman ini termasuk ke dalam anyaman empat sumbu. Teknik dasar anyaman empat sumbu termasuk teknik dasar anyaman yang mempunyai lubang dengan bentuk orthogonal/segi delapan beraturan. Nama lain dari teknik dasar anyaman empat sumbu adalah teknik dasar anyaman segi depalan karena mempunyai lubang dengan bentuk segi delapan beraturan.

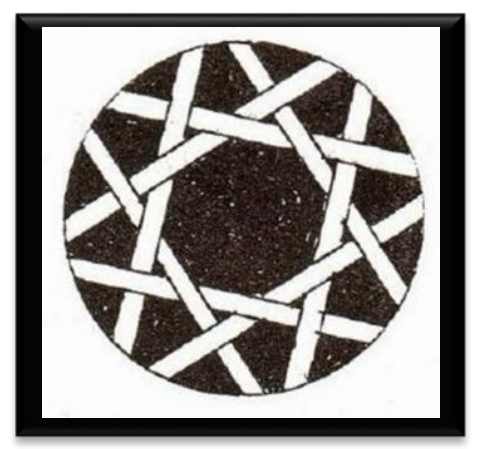

Beberapa unsur matematika yang lain yang ada dalam pola anyaman tersebut diantaranya: bangun geometri segi delapan/orthogonal, membentuk segitiga sama sisi.

\section{Penutup}

Simpulan dalam penelitian ini adalah Etnomatematik dalam bercocok tanan padi pada masyarakan kampung naga diantaranya penghitungan ganjil genap untuk menentukan benih padi yang akan ditanam. Biasanya di semester satu (bilangan ganjil) mereka menanam padi dengan jenis pare alit dan di semester kedua (bilangan genap) mereka menanam padi dengan jenis pare ageung. Dalam menentukan banyaknya bibit yang akan mereka tanam, mereka menggunakan hitungan yang hanya dapat dipakai dan dipahami di lingkungan mereka sendiri. Dalam satu aray (40 bata) masyarakat kampung naga menanam padi hanya sebanyak satu geugeus (2 endan). Etnomatematik dalam kerajinan anyaman

Gambar 7. Unsur Matematika pada Pola Anyaman. 
masyarakat kampung naga adalah adanya penggunaan prinsif teselasi pada pola anyamannya. (1) Teselasi pada kerajinan anyaman tekor sama kipas memiliki pola regular tessellation. Anyaman tengkor menyerupai bangun geometri kerucut dan anyaman kipas menyerupai bangun geometri ellips. Beberapa unsur matematika yang ada dalam pola anyaman tersebut diantaranya: bangun geometri persegi, antara persegi yang satu dengan yang lainnya simetris, sudut-sudut yang dibentuk adalah sudut siku-siku, garis horizontal tegak lurus dengan garis vertikal, antara garis horizontal yang satu dan yang lain saling sejajar, begitu pula antara garis vertical yang satu dengan yang lainnya saling sejajar; (2) Teselasi pada anyaman piring alas buat makan memiliki pola Semiregular Tesselation. Anyaman piring alas berbentuk bangun geometri lingkaran. Beberapa unsur matematika yang lain yang ada dalam pola anyaman tersebut diantaranya: bangun geometri segi enam/heksagonal, sudut yang saling berhadapan sama besar; (3) Teselasi pada kerajinan anyaman piring snek dan rigen piring memiliki pola $A$ Demi Reguler Tesselation. Anyaman piring snek berbentuk bangun geometri ellips dan rigen piring membentuk bangun geometri lingkaran. Beberapa unsur matematika yang lain yang ada dalam pola anyaman tersebut diantaranya: bangun geometri segi delapan/orthogonal, membentuk segitiga sama sisi.

Berdasarkan simpulan dan pembahasan yang telah dideskrifsikan, maka ada beberapa saran diantaranya: untuk peneliti selanjutnya diharapkan dapat melakukan penelitian pada bidang lain, seperti alat music, permqainan, dan adat istiadat lainnya yang ada pada masyarakat kampung naga; jenis-jenis anyaman masyarakat kampung naga dapat dijadikan bahan rujukan untuk menyusun soal pemecaahan masalah matematika kontekstual; Kampung Naga dijadikan alternative pembelajaran maatematika di luar kelas.

\section{Daftar Pustaka}

Afriansyah, E. A. (2016). Investigasi Kemampuan Problem Solving dan Problem Posing Matematis Mahasiswa via Pendekatan Realistic. Mosharafa: Jurnal Pendidikan Matematika, 5(3), 269-280.

Ascher, M. 1991. Ethnomathematics: A Multicultural View of Mathematical Ideas. New York: Capman \& Hall.

Barton, W. D. (1996). Ethnomatemathics: Exploring Culturan Diversity in Mathematics. Auckland: University of Auckland.

Bogdan, R. \& S.J. Tylor, 1993. Kualitatif Dasar-Dasar Penelitian (terjemahan), Surabaya: Usaha Nasional.

D'Ambrossio, U.

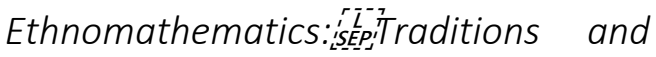
Modernity. Sao Paulo. Brazil: Sense Publishers.

D’Ambrossio, U. 2001 Ethnomathematics: link between iśE-Titraditions and Modernity. Sao Paulo. Brazil: Sense Publishers

D'Ambrosio, Ubiratan. 1985. Ethnomathematics and Its Place in the History and Pedagogy of 
Mathematics. Tersedia pada http://www.math.utep.edu/Faculty/p mdelgado2/Math1319/History/DAmbr osio.pdf. Diunduh tanggal 22 agustus 2018.

Edo, S. I. \& Samo, D. D. (2017). Lintasan Pembelajaran Pecahan Menggunakan Matematika Realistik Konteks Permainan Tradisional Siki Doka. Mosharafa: Jurnal Pendidikan Matematika, 6(3), 311-322.

Lexy J, Moleong. 2010. Metodologi Penelitian Kualitatif. Bandung: PT Remaja Rosdakarya.

Maryati, I. \& Priatna, N. (2017). Integrasi Nilai-Nilai Karakter Matematika melalui Pembelajaran Kontekstual. Mosharafa: Jurnal Pendidikan Matematika, 6(3), 333-344.

O'Daffer, Phares G. 2008. Mathematics for Elementary School Teachers. Fourth Edition. Pearson Education.

Rokhmah, Siti, dkk. 2010. Empowering Student's Creativity Through Learning Tessellation Using the Internet. Tersedia pada http://ifed.or.id/v2/index.php?option =com_content\&view=article\&id=147: empowe ring-students-creativitythrough-learning-tesselation-usingtheinternet\&catid $=45$ : pendidkan\&/temid=54\&lang=in.

Diunduh tanggal 22 agustus 2018

Rosa, M. dan Orey, D. C. (2011). Ethnomatematics: The cultural aspects of mathematics. Revistas Latinoamericana de Etnomatematica, Vol. 4 No. 2 hlm. 32-54

Wilder, R. L. (1950). Cultural basic of Mathematics: An International Congress of
cs.standrews.ac.uk/Extras/Cultural Ba sis I.html (diakses tanggal 26 Januari 2018).

\section{Riwayat Hidup PENUlis}

Vepi Apiati, M. Pd.

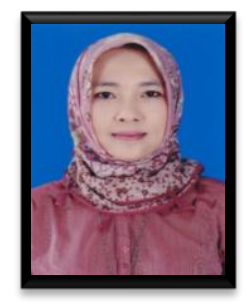

Lahir di Ciamis, 27 April 1975. Jurusan Pendidikan Matematika FKIP Universitas Siliwangi. Studi S1 Pendidikan Matematika FKIP Universitas Siliwangi, Tasikmalaya, lulus tahun 1998; Studi S2 Pendidikan Matematika Universitas Pendidikan Indonesia (UPI), Bandung, lulus tahun 2012; Menulis buku Aplikasi Matematika.

\section{Yeni Heryani, M. Pd.}

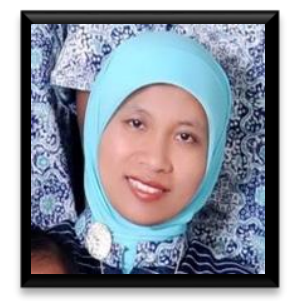

Lahir di Ciamis, o9 Januari 1980. Jurusan Pendidikan Matematika FKIP Universitas Siliwangi. Studi S1 Pendidikan Matematika FKIP Universitas Siliwangi, Tasikmalaya, lulus tahun 2003; Studi S2 Pendidikan Matematika Universitas Terbuka UPBJJ UT Bandung, lulus tahun 2014.

\section{Siska Ryane Muslim, M. Pd.}

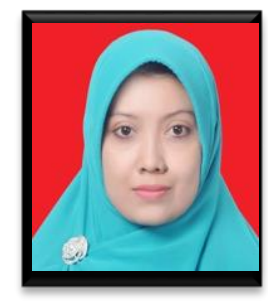

Lahir di Tasikmalaya, 28 Januari. Jurusan Pendidikan Matematika FKIP Universitas Siliwangi. Studi S1 Pendidikan Matematika FKIP Universitas Siliwangi, Tasikmalaya, lulus tahun 2004; Studi S2 Pendidikan Matematika Universitas Terbuka UPBJJ UT Bandung, lulus tahun 2014.

Mathematicians,http://wwwhistory.m 